\section{An autochthonous case of visceral canine leishmaniasis in Barra do Piraí-RJ}

\section{Caso autóctone de Leishmaniose Visceral Canina em Barra do Piraí-RJ}

\author{
Flavia Clare Goulart de Carvalho (D), Raphaela Fernandes Coelho² (D), Gabriele Barbosa Brandão² (D), \\ Artur Augusto Velho Mendes Júnior ${ }^{3}$ (1) \& Bruna de Azevedo Baêta** (i) \\ 'Veterinary, Dr. Universidade de Vassouras, Vassouras, RJ, Brasil \\ ${ }^{2}$ Graduating, Veterinary. Universidade de Vassouras, Vassouras, RJ, Brasil \\ ${ }^{3}$ Veterinary, Technician. Laboratório de Pesquisa Clínica em Dermatozoonoses, Instituto de Pesquisa Clínica Evandro Chagas, \\ Fundação Oswaldo Cruz, Rio de Janeiro, RJ, Brasil
}

\begin{abstract}
Visceral leishmaniasis, caused by the protozoan Leishmania chagasi, is a re-emergent anthropozoonosis and has become a major public health problem. In urban areas, dogs (Canisfamiliaris) are the main source of infection to humans. The canine enzootic disease precedes and is more prevalent that the human disease. The present study reports an autochthonous case of visceral canine leishmaniasis in Barra do Piraí, Rio de Janeiro. After detecting clinical signs consistent with canine visceral leishmaniasis, several diagnostic tests were performed, such as cytological examination of the ear tip and lymph node puncture, rapid immunochromatographic test, dual path platform, enzymatic immunoadsorption assay, indirect immunofluorescence assay, and culture of material obtained from skin biopsy and lymph node and bone marrow punctures. After clinical, serological, and parasitological confirmation of Leishmania, the dog's owner chose to euthanize it and, 3 months later, another positive animal residing in the same place was also euthanized. Based on this report, it is necessary to conduct entomological and epidemiological surveillances in Barra do Piraí to detect the presence of the vector and/or canine enzootic disease before initiation of the anthropozoonotic cycle, allowing actions to control the disease in canines and prevent its occurrence in humans.
\end{abstract}

Keywords: Visceral leishmaniasis, dogs, diagnostic.

\section{Resumo}

Leishmaniose Visceral, causada pelo protozoário Leishmania chagasi, é uma antropozoonose re-emergente, considerada um grande problema de saúde pública. Na área urbana, o cão (Canis familiaris) é a principal fonte de infecção para humanos. A enzootia canina precede é mais prevalente que a doença em humanos. O presente estudo relata a ocorrência de um caso autóctone de Leishmaniose Visceral Canina em Barra do Piraí, RJ. Após constatação de clínica compatível com leishmaniose visceral canina, foram realizados diversos exames para diagnóstico da doença como citologia de ponta de orelha e punção aspirativa por agulha fina de linfonodos, teste rápido imunocromatográfico Dual Path Platform, ensaio de imunoadsorção enzimática, reação de Imunifluorescência indireta e cultura de material obtido a partir de biópsia de pele e punção aspirativa de linfonodos e medula óssea. Com a confirmação clínica, sorológica e parasitológica de Leishmania spp. o proprietário optou por eutanasiar este animal e após 3 meses um outro animal positivo residente no mesmo local. Este relato evidencia a necessidade de implementação de ações de vigilância entomológica e epidemiológica no município de Barra do Piraí, com intuito de detectar a presença do vetor e/ou a enzootia canina antes da instalação do ciclo antropozoonótico, permitindo ações para controlar a doença em caninos e prevenir sua ocorrência em humanos.

Palavras-chave: Leishmaniose visceral, cães, diagnóstico.
How to cite: Carvalho, F. C. G., Coelho, R. F., Brandão, G. B., Mendes Junior, A. A. V., \& Baêta, B. A. An autochthonous case of visceral canine leishmaniasis in Barra do Piraí-RJ. Brazilian Journal of Veterinary Medicine, (41), e099019. https://doi.org/10.29374/2527-2179.bjvm099019

\section{Financial support: FUSVE.}

Conflict of interests: No conflict of interests declared concerning the publication of this article.

Received: August 13, 2018. Accepted: March 25, 2019.

The study was carried out at Universidade de Vassouras and Laboratório de Pesquisa Clínica em Dermatozoonoses, Instituto de Pesquisa Clínica Evandro Chagas, Fundação Oswaldo Cruz.

\section{*Correspondence}

Bruna de Azevedo Baêta

Universidade de Vassouras

Av. Expedicionário Oswaldo de Almeida

Ramos, 280, Centro

CEP 27700-O00 - Vassouras (RJ), Brasil

E-mail: babaeta@hotmail.com 


\section{Introduction}

American visceral leishmaniasis (AVL) is a zoonosis that has become a major public health problem because of the extensive geographic distribution, high incidence, and the seriousness of its clinical forms (World Health Organization, 2015). It is caused by the protozoa Leishmania infantum (Leishmania chagasi) (Dantas-Torres, 2006) and transmitted mainly through the bite of female sandflies (Tavares \& Marinho, 2012; Brasil, 2014).

Domestic dogs are the host, playing an important role in perpetuating the parasite's biological cycle in urban areas (Baneth et al., 2008), where cases of canine visceral leishmaniasis (CVL) coexist with the human disease at all known foci but are more prevalent and generally precede the occurrence of the human disease (Camargo-Neves et al., 2001). Thus, dogs can be considered as sentinels.

With significant increase in the number of cases and expansion of the disease incidence area, CVL was prioritized by the World Health Organization among tropical diseases. CVL has been reported in all continents, except in Antarctica and Oceania (World Health Organization, 2015). The disease is endemic in 12 countries in North and South America located between Mexico and Argentina (Grimaldi Junior et al., 1989), among which 90\% of the reports are from Brazil, with higher incidences in the North, Northeast, and Central-West regions (Grimaldi Junior et al., 1989; World Health Organization, 2015). In Rio de Janeiro (RJ), CVL was unknown until mid-1977, when the first case was reported in the western region (Salazar et al., 1979), and since then, although infection control has been achieved in the affected areas, cases CVL remain. (Marzochi et al., 2009).

\section{Case report}

In December 2016, a two-year-old male mongrel, born and domiciled in Barra do Piraí, RJ, with no travel history, was consulted by a private veterinarian, and after finding clinical signs compatible with CVL, was treated with fine-needle aspiration cytology of the ear tip and lymph node puncture. Staining with Rapid Panoptic Staining revealed countless amastigote forms of Leishmania in the macrophage cytoplasm, which eventually ruptured (Figure 1). In addition, the serological tests indirect immunofluorescence assay (IIFA) and indirect enzymatic immunoadsorption assay (iELISA) were performed at a private laboratory, both of which showed positive for CVL, with an antibody titer of 1:80 in the IIFA.

The mongrel was sent to the dermatology department of the Veterinary Hospital at Universidade de Vassouras, where clinical examination and dual path platform (DPP ${ }^{\circ}$ immunochromatographic rapid test were performed, and the other animals residing at the same address were tested. Two of the four tested animals were detected positive with the rapid test, although one of them presented no clinical signs.

Clinical examination revealed clinical signs consistent with AVL, including mild jaundice, generalized adenitis, progressive thinning, furfuraceous skin, crustal and ulcerated lesions in the ear tip region, crustal lesions in the nasal plane and periorbital region, and circular and crustal lesions in the right posterior limb (Figure 2).

At the Fundação Oswaldo Cruz (FIOCRUZ-RJ), the serological tests were repeated and, after confirming the diagnosis, the mongrel was sedated with ketamine $(10 \mathrm{mg} / \mathrm{kg})$ combined with acepromazine $(0.2 \mathrm{mg} / \mathrm{kg})$ and treated with bone marrow and lymph node punctures. In addition, local anesthesia using an anesthetic button with lidocaine was induced for biopsies of whole skin and cutaneous lesions to isolate parasites in culture media. Materials were stored in saline and seeded in the Novy-MacNeal-Nicolle biphasic culture medium containing Schneider's medium, supplemented with $10 \%$ fetal bovine serum as the liquid phase. In all the samples, promastigote forms of Leishmania were isolated after 30 days of culture.

After clinical, serological, and parasitological confirmation of Leishmania, the mongrel's owner chose to euthanize it, and, after 3 months, the other positive animal was also euthanized (without clinical symptomatology).

An entomological survey was conducted using two Center for Disease Control light traps: 1) near the kennel; and 2) near the adjacent bamboo forest. The traps were placed at 6:00 p.m. and removed at 7:00 a.m. the following morning for 3 consecutive days; however, no sandflies were observed. 


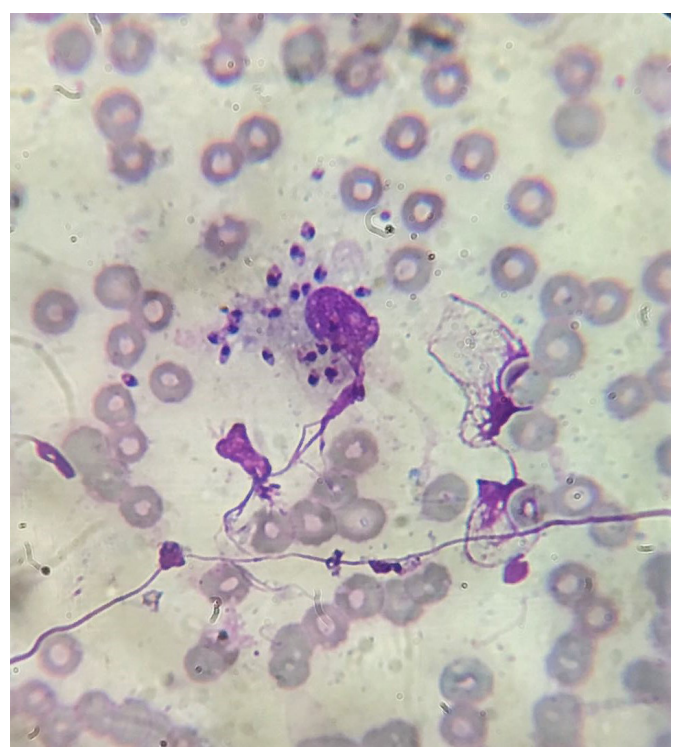

Figure 1. Ear tip cytology stained with Rapid Panoptic Staining presenting Leishmania spp. in the macrophages' cytoplasm, amplification of 1000x.

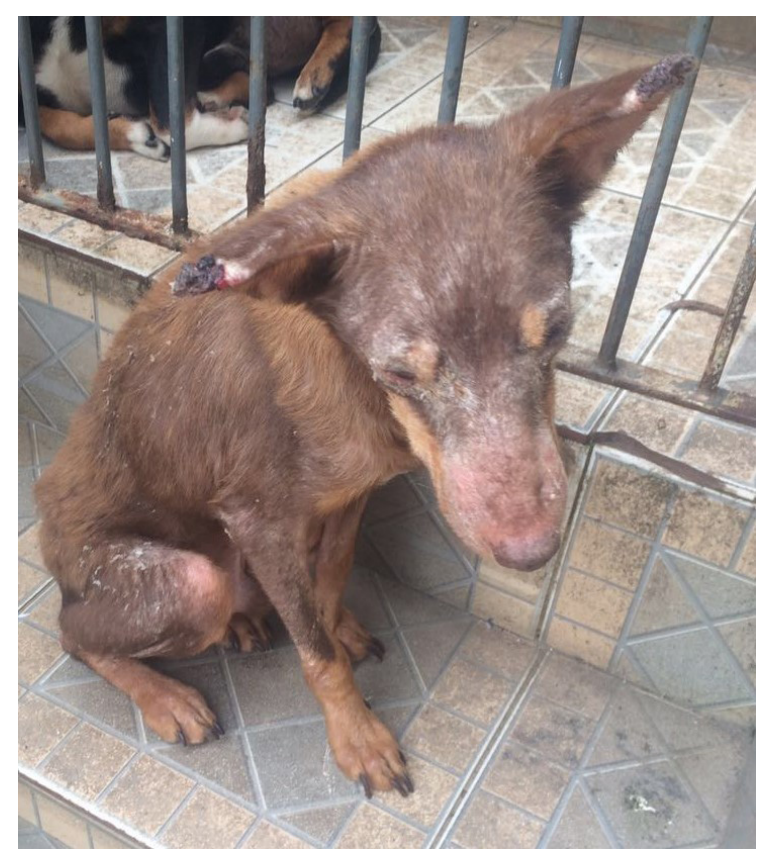

Figure 2. Animal with crustal lesions suggestive of Canine Visceral Leishmaniasis.

\section{Discussion}

This is the first autochthonous case of CVL reported in Barra do Piraí.

The mongrel in this report had clinical signs that could be misdiagnosed as other diseases. According to Ribeiro (2016), clinical signs of CVL can be confused with those of several other diseases, and therefore, further examinations are required to diagnose CVL.

The lymph node aspirate revealed countless forms of amastigotes. According to Laurenti (2009), direct observation of the parasite in aspirates and imprints has a specificity of $100 \%$ and provides a rapid and reliable diagnosis, depending on the staining technique and observer's ability to identify the amastigote forms. Lima et al. (2014) described that lymph nodes are favorable for parasitological confirmation. 
Additionally, a rapid test and skin biopsy were preformed, and the material was subjected to protozoan culture and an iELISA test to confirm the diagnosis of CVL. Moreira et al. (2007) affirmed the need of more than one exam to avoid false-negative results.

Although no vectors of Leishmania were found, it should be considered that sandflies are difficult to capture, especially on dry days. In tropical areas, their population density increases during and after rainy periods because of the high humidity (Almeida et al., 2010). Thus, long dry periods can lead to population reduction. The distribution of sandflies is based on several factors, such as altitude, climate, soil type, rainfall (Forattini, 1960; Kassem et al., 2012), and moon phases.

Several cities in Rio de Janeiro have been reporting cases of CVL (Campos et al., 2013; Mello et al., 2014). CVL usually precedes and is more prevalent than the human infection (Campino, 2002). Therefore, it is important to conduct entomological and epidemiological surveillances in Barra do Piraí to detect the presence of the vector and/or canine enzootic disease before initiation of the anthropozoonotic cycle, thereby allowing actions to control the disease in canines and prevent its occurrence in humans.

\section{References}

Almeida, P. S., Nascimento, J. C., Ferreira, A. D., Minzão, L. D., Portes, F., Miranda, A. M., Faccenda, O., \& Andrade Filho, J. D. (2010). Espécies de flebotomíneos (Diptera, Psychodidae) coletadas em ambiente urbano em municípios com transmissão de Leishmaniose Visceral do Estado de Mato Grosso do Sul, Brasil. Revista Brasileira de Entomologia, 54(2), 304-310. http://dx.doi.org/10.1590/S0085-56262010000200014.

Baneth, G., Koutinas, A. F., Solano-Gallego, L., Bourdeau, P., \& Ferrer, L. (2008). Canine leishmaniosis - new concepts and insights on an expanding zoonosis: part one. Trends in Parasitology, 24(7), 324-330. http:// dx.doi.org/10.1016/j.pt.2008.04.001. PMid:18514028.

Brasil. Ministério da Saúde. Secretaria de Vigilância em Saúde. (2014). Manual de vigilância e controle da leishmaniose visceral (1. ed., 5. reimpr.). Brasília: Departamento de Vigilância Epidemiológica.

Camargo-Neves, V. L. F., Katz, G., Rodas, L. A. C., Poletto, D. W., Lage, L. C., Spínola, R. M. F., \& Cruz, O. G. (2001) Utilização de ferramentas de análise espacial na vigilância epidemiológica de leishmaniose visceral americanaAraçatuba, São Paulo, Brasil, 1998-1999. Cadernos de Saude Publica, 17(5), 1263-1267. http://dx.doi.org/10.1590/ S0102-311X2001000500026. PMid:11679900.

Campino, L. (2002). Canine reservoirs and leishmaniasis: epidemiology and disease. In JP Ferrel (Ed.), World class parasites, Leishmania (pp. 45-57). Boston: Kluwer Academic Publishers. http://dx.doi.org/10.1007/978-1-4615-0955-4_4.

Campos, M. P., Silva, D. A., Madeira, M. F., Velho Júnior, A. A. M., \& Figueiredo, F. B. (2013). First autochthonous case of canine visceral leishmaniasis in Volta Redonda, Rio de Janeiro, Brazil. Revista Brasileira de Parasitologia Veterinária, 22(3), 424-426. http://dx.doi.org/10.1590/S1984-29612013000300018. PMid:24142177.

Dantas-Torres, F. (2006). Leishmania infantum versus Leishmania chagasi: do not forget the law of priority. Memorias do Instituto Oswaldo Cruz,101(1), 117-118, discussion 118. http://dx.doi.org/10.1590/S0074-02762006000100024. PMid:16699722.

Forattini, O. P. (1960). Sobre os reservatórios naturais da Leishmaniose Tegumentar Americana. Revista do Instituto de Medicina Tropical de São Paulo, 2, 195-200.

Grimaldi Junior, G., Tesh, R. B., \& Mcmahon-Pratt, D. (1989). A review of geographical distribution and epidemiology of leishmaniasis in the New World. The American Journal of Tropical Medicine and Hygiene, 41(6), 687-725. http://dx.doi.org/10.4269/ajtmh.1989.41.687. PMid:2701633.

Kassem, H. A., Siri, S., Kamal, H. A., \& Wilson, M. L. (2012). Environmental factors underlying spatial patterns of sand flies (Diptera: Psychodidae) associated with leishmaniasis in southern Sinai, Egypt.Acta Tropica, 123(1), 8-15. http://dx.doi.org/10.1016/j.actatropica.2012.02.067. PMid:22410540.

Laurenti, M. D. (2009). Correlação entre o diagnóstico parasitológico e sorológico na leishmaniose visceral americana canina. Boletim Epidemiológico Paulista, 6(67), 13-23.

Lima, M. A. M., Maia, J. S., Zanetti, K., Reginaldo, A. S., \& Braz, P. H. (2014). Comparação da sensibilidade do teste parasitológico em linfonodo, medula óssea e mucosa conjuntival para o diagnóstico de leishmaniose em cães. Acta Veterinaria Brasilica, 8(4), 274-276.

Marzochi, M. C., Fagundes, A., Andrade, M. V., Souza, M. B., Madeira, M. F., Mouta-Confort, E., Schubach, A. O., \& Marzochi, K. B. F. (2009). Visceral leishmaniasis in Rio de Janeiro, Brazil: ecoepidemilogical aspects and control. Revista da Sociedade Brasileira de Medicina Tropical, 42(5), 570-580. http://dx.doi.org/10.1590/5003786822009000500017. PMid:19967242.

Mello, C. X., Figueiredo, F. B., Mendes Júnior, A. A. V., Furtado, M. C., Miranda, L. F. C., \& Madeira, M. F. (2014) Outbreak of canine visceral leishmaniasis in Barra Mansa, State of Rio de Janeiro. Revista da Sociedade Brasileira de Medicina Tropical, 47(6), 788-790. http://dx.doi.org/10.1590/0037-8682-0042-2014. PMid:25626661.

Moreira, M. A., Luvizotto, M. C., Garcia, J. F., Corbett, C. E., \& Laurenti, M. D. (2007). Comparison of parasitological, immunological and molecular methods for the diagnosis of leishmaniasis in dogs with different clinical signs. Veterinary Parasitology, 145(3-4), 245-252. http://dx.doi.org/10.1016/j.vetpar.2006.12.012. PMid:17257764. 
Ribeiro, V. M. (2016). Leishmaniose Visceral Canina, considerações do diagnóstico e tratamento nos dias atuais. Veterinary Sciences, 12, 44.

Salazar, M. C., Pinto, F. C., Gouveia, L. R., Bacha, P. C., \& Salgueiro, P. F. (1979). Leishmaniose visceral (relato de um caso autóctone na cidade do Rio de Janeiro). Revista Médica, 8, 19.

Tavares, W., \& Marinho, L. A. C. (2012). Rotinas de diagnóstico e tratamento das doenças infecciosas e parasitárias (pp. 695-700, 3. ed.). Atheneu.

World Health Organization - WHO. (2015, february). Leishmaniasis (Fact Sheet, no. 375). Retrieved in 2018, janeiro 1, from http://www.who.int/mediacentre/factsheets/fs375/en/ 